\title{
The Effect of Authentic Leadership in Increasing Employees' Psychological Capital and Creativity Moderated by Job Satisfaction
}

\author{
M Senen HAR ${ }^{1}$, Ali Sadikin ${ }^{2}$ \\ ${ }^{1}$ Management, STIE APRIN Palembang, Indonesia \\ ${ }^{2}$ Management, STIE APRIN Palembang, Indonesia,
}

\begin{abstract}
:
This study aims to determine the effect of authentic leadership in increasing employees psychological capital and creativity moderated by job satisfaction. This type of research used in this research is quantitative. This research was conducted at the Telecommunications Company (Telkom). The sample used in this study amounted to 100. The data used are quantitative data by collecting primary data and secondary data. (1) primary data, in the form of distributing questionnaires in the field to employees of Telecommunications Company (Telkom) and (2) secondary data in this study. are literature, books, literature studies, and online media that can be found in libraries or the internet as supporting information for this research. The analysis used in this research is using smart PLS software to determine the effect of the independent, moderation and dependent variables. The independent variable in this study is authentic leadership (X1), the dependent variable is psychological capital (Y1) and creativity (Y2), while the moderating variable is job satisfaction $(Z)$. The results showed that the authentic leadership variable had a positive and significant effect on Creativity. Authentic leadership has a positive and significant effect on psychological capital. authentic leadership moderated job satisfaction has an influence on creativity. authentic leadership moderated by job satisfaction has an influence on psychological capital. The independent variable in this study is authentic leadership (X1), the dependent variable is psychological capital (Y1) and creativity (Y2), while the moderating variable is job satisfaction (Z). The results showed that the authentic leadership variable had a positive and significant effect on Creativity. Authentic leadership has a positive and significant effect on psychological capital. authentic leadership moderated job satisfaction has an influence on creativity. authentic leadership moderated by job satisfaction has an influence on psychological capital. The independent variable in this study is authentic leadership (X1), the dependent variable is psychological capital (Y1) and creativity (Y2), while the moderating variable is job satisfaction (Z). The results showed that the authentic leadership variable had a positive and significant effect on Creativity. Authentic leadership has a positive and significant effect on psychological capital. authentic leadership moderated job satisfaction has an influence on creativity. authentic leadership moderated by job satisfaction has an influence on psychological capital. The results showed that the authentic leadership variable had a positive and significant effect on Creativity. Authentic leadership has a positive and significant effect on psychological capital. authentic leadership moderated job satisfaction has an influence on creativity. authentic leadership moderated by job satisfaction has an influence on psychological capital. The results showed that the authentic leadership variable had a positive and significant effect on Creativity. Authentic leadership has a positive and significant effect on psychological capital. authentic leadership moderated job satisfaction has an influence on creativity. authentic leadership moderated by job satisfaction has an influence on psychological capital.
\end{abstract}

Keywords: Authentic Leadership, Employees Creativity, Job Satisfaction.

\section{Introduction}

One of the efforts that can be made to improve the quality of human resources in order to gain competitive advantage is to increase employee creativity. (Tayibnapis, AZ, Wuryaningsih, LE, \&
'Psychological Capital, Employees' Psychological

Gora, 2018). Employees who have creativity will produce better performance. Employees who have creativity have new ideas and perspectives that will help the work process. (Lee, 2018). Creativity itself can be formed by several things, the first is affective commitment from employees (Semedo et al, 2016). 
Employees who bind themselves to the organization because the employee is happy with the conditions of the organization, will be more open minded to finding new things. Conversely, employees who do not feel comfortable with the organization will have their minds closed. (Allen, DG, \& Shanock,

Creativity is important for organizational health in today's economy, because by encouraging creative and innovative behavior of employees, they can gain and maintain a competitive advantage (Slåtten, T., \& Mehmetoglu, 2015). Many organizations depend on employee creativity to gain competitive advantage, adapt and for their survival (Hsieh, YH, \& Chen, HM 2011). Therefore, understanding the dynamics of creativity in an organization is a high priority for organizational behavior research (Schreyögg, G., \& Sydow, 2010). Employee creativity is influenced by two factors, namely internal and external. Internal factors come from within employees such as personality and cognitive style (Chen, MH, Chang, YY, \& Chang, 2015).

One of the factors that affect employee creativity is leadership, good and appropriate leadership will have a positive impact on employees in creating creative ideas in order to increase competitive advantage. (Kremer, H., Villamor, I., \& Aguinis, 2019). This is in accordance with the statement of Insoll, L., \& Mäkikyrö, (2018) which states that when the boss provides a supportive atmosphere of creativity, the mood will be positively related to employee creativity. A positive mood increases selfconfidence and different thinking and contributes to creativity while working in an organization.

Increased personal understanding of psychological antecedents to creativity can inform efforts to create and foster individual creativity. The author proposes that psychological capital can help explain and predict creative behavior, especially idea generation (Gong, Y., Cheung, SY, Wang, M., \& Huang, 2012).

According to (Avey, JB, Luthans, F., \& Youssef, 2010) psychological factors are the capital that shape positive and creative behavior. Good psychological qualities, a positive work attitude, and a stable mental state can lead to optimal work performance. In Sweetman \& Luthans (2010), it is explained that the psychological capacity in individuals who develop positively is called psychological capital. According to Verleysen, Lambrechts, \& Van Acker (2015) psychological capital is a positive condition that exists in an individual. In the end psychological capital needs to be considered by the company because it will have an impact on the desired work results such as the attitudes desired by employees (job satisfaction, organizational commitment, psychological wellbeing), desired employee behavior, and performance (Avey, JB, Luthans, F., Smith, RM,

Psychological capital can also be influenced by various factors, one of which is the form of leadership. (Toor, SUR, \& Ofori, 2010). The leader is someone who is responsible for not achieving the company's targets. Leaders who are less competent will result in employees being less disciplined at work. Employees who are less disciplined result in sub-optimal performance and result in not achieving company targets. (Dul, J., Bruder, R., Buckle, P., Carayon, P., Falzon, P., Marras, WS, ... \& van der Doelen, 2012). The attitudes and behaviors shown by these leaders are then observed and then have an influence on the psychological capital of employees (Rego, A., Sousa, F., Marques, C., \& e Cunha, 2012). In line with the statement Amunkete \&

Leadership is an individual's ability to influence a group towards achieving goals. (Wu, JB, Tsui, AS, \& Kinicki, 2010). said leadership is a person's ability to influence his subordinates to be able to do the will of his leader. (Sauer, 2011). Yukl (in Jex \& Britt, 2008), leadership style is also defined as an assessment that involves influencing organizational goals and strategies, influencing organizational members to achieve goals, influencing organizational management and influencing organizational culture (García-Morales, VJ, Jiménez-Barrionuevo , MM, \& Gutiérrez-Gutiérrez, 2012).

One form of leadership is authentic leadership. Khan, 2010) explains that authentic leadership is a combination of transformational leadership and ethical leadership, where leaders are not only able to motivate employees but authentic leaders will act according to certain moral standards and beliefs and are able to create a positive environment in the workplace with the aim of gaining credibility. and trust from subordinates, and build cooperation with subordinates.

There are several research results which state that external factors such as leadership style can stimulate employee innovative behavior. Pieterse Knippenberg, Schippers, \& Stam (2010) state that there is a significant influence between transformational leadership on innovative behavior. Another study explains that transformational leaders are able to motivate and stimulate radio broadcasters 
to make changes and make innovations to provide another touch during broadcast (Loon, M., Lim, YM, Lee, TH, \& Tam, 2012). Based on the description above, it can be said that transformational leadership is leadership that is able to motivate and stimulate subordinates to improve performance and generate innovative work behavior. Liu, Liao, \& Wei (2015) explain that authentic leadership can increase the attachment and satisfaction of subordinates and strengthen the identity of subordinates positively towards the organization. Olaniyan (2017) explains that authentic leadership is able to optimally create a healthy and comfortable work environment for employees in the organization.

Apart from authentic leadership, psychological capital and creativity can also be affected by job satisfaction. (Jung, HS, \& Yoon, 201). Job Satisfaction itself is a pleasant state or positive emotion resulting from a job appraisal or someone's work experience. (Dugguh, \& Dennis, 2014). Job Satisfaction is generated from employees' perceptions of how well and how important the job is. The existence of Job Satisfaction will lead to an increase in an employee's commitment to the organization (Han et al., 2012) so that it can be said that the Job Satisfaction provided by the organization is such as salary, recognition, supervision, good cooperation with colleagues, and opportunities for develop (Parvin, MM, \& Kabir, M. $\mathrm{N}$,

\section{Theoritical review}

\subsection{Psychological Capital}

Psychological capital is a positive psychological approach in the field of psychology. According to Luthans \& Youssef (2017) psychological capital is a conceptual model of a positive approach to the workplace known as the concept of positive organizational behavior (POB) theory. Luthans \& Youssef (2017) develop psychological capital or better known as PsyCap to capture individual psychological capacities that can be measured, developed and utilized for performance improvement. Psychological capital is an approach characterized by dimensions that can optimize the potential of an individual so that it can help organizational performance (Luthans \& Youssef, 2017). These dimensions are self-efficacy (selfefficacy), hope (hope), optimism (optimism), and resilience (resilience). This positive psychological capital can be developed optimally. Optimization of this positive psychological model will help someone improve their performance. So that they can foster innovative behavior that is supported by an attitude of optimism and employee confidence in completing the task at hand (Luthans, F., \& Youssef-Morgan, 2017).

PsyCap in (Avey, JB, Reichard, RJ, Luthans, F., \& Mhatre, 2011) is stated as a state of positive individual psychological development with the following indicators:

1. Have the confidence (self efficacy) to take and make an effort necessary for the success of the task at hand,

2. Provide positive responses (optimism) for present and future successes,

3. Be persistent and persistent towards goals and if needed, organize efforts to achieve goals (hope) in order to achieve success

4. If you face problems and failures, stay afloat and bounce back, and be even stronger than before (resiliency) to achieve success.

Authentic leadership affects psychological capital. Employees who work under an authentic leader will have a high level of psychological capital, this is because their leader has self-awareness, is transparent, is regulated by his own ethical standards and has the ability to objectively analyze all relevant data (Malik and Dhar, 2017). This is supported by research conducted by Olaniyan and Hystad (2016), which found that authentic leadership has a positive influence on psychological capital.

\subsection{Creativity}

According to Fazylova \& Rusol (2016) defining creativity as a means of expression and reflection of humans in the world around them. Creativity has become a "hot" topic and an important agenda in the last two decades (Jaussi \& Dionne 2003; Joo, McLean, \& Yang 2013). Employee creativity is important because it is a starting point or the beginning of innovation (Chini, 2011). When employees display creative performance, they suggest new and useful ideas for the organization that are a prerequisite for further development and implementation (De Stobbeleir, KE, Ashford, SJ, \& Buyens, 2011). There are several indicators of creativity according to Putri, A., Kartini, K., \& Yuanita (2020).

1. Skills The ability to do something about a role. It is an ability that can be transferred from one person to another.

2. Thinking ability The thinking power that must be built in work so that it becomes a character 
or personality that is embedded in work life to solve all the problems of his life by identifying any information he receives then being able to evaluate and then summarize it systematically and then able to express opinions in an organized way.

3. Motivation The process that describes the intensity, direction, and persistence of an individual to achieve his goals.

4. Discipline The feeling of being obedient and obedient to the values that are believed is his responsibility.

5. Smoothness The ability to generate many ways of compliance by the company.

Authentic leadership will have a positive impact on employees in creating creative ideas in order to increase competitive advantage. This is in accordance with research conducted by Avolio, Wernsing, and Gardner (2018) which states that authentic leadership is able to increase subordinate attachment and satisfaction and strengthen the identity of subordinates positively towards the organization so that it will create synergistic and creative company resources.

\subsection{Authentic Leadership}

Rego, Sousa, Marque, Cunha (2012) define authentic leadership as a pattern of behavior that describes a leader who makes good use of his abilities. Both in terms of increasing positive psychological capacity, positive ethical climate, high self-awareness, moral behavior, balanced and transparent processing of information on relationships, and able to encourage positive selfdevelopment. (Hannah, Avolio, Walumbwa, 2011). Authentic leadership can increase the engagement and satisfaction of subordinates and strengthen the identity of subordinates positively towards the organization (Gigol, 2020). Weiss, et al (2018) state that authentic leadership is a combination of transformational leadership and ethical leadership,

Sharma, Agrawal, \& Khandelwal (2019) state that authentic leadership is a process of building legitimacy or leader's policy through honest relationships, appreciating input to subordinates, and being built on an ethical foundation. Based on the above opinion, it can be formulated that authentic leadership is a leader who has the ability to utilize and promote his / her abilities, such as high selfawareness, good, fair and transparent ethics and morals to followers. The goal is to influence subordinates, and to be able to build a healthy environment and create positive relationships with subordinates to gain the trust of employees. (Bamford, M., Wong, CA, \& Laschinger, 2013). This can increase the reciprocal behavior of employees and increase employee satisfaction with leaders and organizations in the workplace. Employee satisfaction with the leader becomes the benchmark for employees to innovate, because feeling satisfied with the workings of the leader, employees will give feedback to the leader and the organization in the form of improving performance and developing their own innovations. (Maharani, Roena, and Noermijati, 2013).

Amunkete, S., \& Rothmann (2015) stated that authentic leadership consists of four aspects, namely:

1. Self-awareness (self-awareness) Self-awareness is the way a person sees himself from time to time, is able to understand himself, is able to interpret the world from the process that has been passed. As well as being able to understand the 20 strengths and weaknesses they have, thus a person is able to realize the impact he has on others. For example, encouraging subordinates to express their opinion.

2. Relational transparency (transparent relations) A transparent relationship is the behavior of showing its true self without being made. This behavior is the open disclosure of various information, and shows the expression of real thoughts and feelings, thereby giving rise to trust from others in him through this openness. For example, expressing emotions in accordance with prevailing feelings and values without being hidden.

3. Balanced processing (processing that is balanced) Balanced processing is the behavior of leaders which shows that they analyze all data in a relevant and objective manner before making a decision. The leader also asks for other people's views, and accepts input and criticism from others who oppose their opinion. For example, making decisions objectively and being willing to accept input from others.

4. Internalized moral perspective (internalization of moral perspective) Internalization of moral perspective is a person's ability to control or regulate himself. Self-regulation is in accordance with internalized and integrated moral standards and values in accordance with the morals of the group, organization and society. So as to produce decision making in 
accordance with moral standards that have been internalized. For example, being able to control actions and speech, because the individual realizes that certain words and actions can have an impact on others.

Based on the description above, in this study the researchers used aspects from Petan, L., \& Bocarnea (2016). These aspects are self-awareness, relational transparency, balanced processing. and internalized moral perspective (internalizing moral perspective).

\subsection{Job Satisfaction}

According to Choi, YG, Kwon, J., \& Kim (2013) job satisfaction is a form of emotional attitude that is fun and loves the job they are doing. Job satisfaction at work is job satisfaction that can be enjoyed at work by getting results from the achievement of work goals, placement, treatment, and a good work environment (Lane, KA, Esser, J., Holte, B., \& McCusker, 2010) . Employees who can enjoy job satisfaction in this job, will choose to prioritize their work rather than the remuneration / wages they get from the job. Employees will feel more satisfied if the remuneration is proportional to the work done. (Tan, TH, \& Waheed, 2011).

According to Jehanzeb, K., \& Mohanty (2018). Job satisfaction is functioned to increase employee morale, increase productivity, reduce absenteeism levels, increase employee loyalty and retain employees to continue working in a company. Employees who get job satisfaction are employees who have a good work attendance and turnover, are passive in a work union, and have better work performance than other employees. (Frooman, J., Mendelson, MB, \& Murphy, 2012). While employees who do not get job satisfaction will have an impact on the company in the form of employee absenteeism, work turnover, inaction in completing work, early resignation, being active in a work union, disturbed by the physical and mental health of their employees. (Yucel, 2012).

According to Luthans (2017) there are five indicators that can affect employee job satisfaction, namely:

1. Payments, such as salaries and wages. It is the amount of payment received by employees as a result of performing work.

2. The work itself is the content of the work done by a person. If employees feel that the work done is something meaningful, useful and important, it tends to create Job Satisfaction.

3. Colleagues Namely friends with whom someone always interacts in carrying out work. Colleagues can be a source of employee satisfaction. Employees who are given the opportunity to interact with each other tend to have higher Job Satisfaction than employees who are given less time to interact, so they feel isolated and do not belong to the organization.

4. Promotion. That is the possibility that a person can develop through a promotion. Promotion occurs when an employee moves from a job to another higher position, with responsibilities and organizational levels.

5. Supervision (supervision) It is an attempt to coordinate employees and bridge the gap between management and executive employees. Supervision has an important role in management. Supervision deals with employees directly and influences employees in doing their job. Generally, employees prefer to have supervision that is fair, open and willing to cooperate with subordinates.

\subsection{Thinking Framework and Hypotheses}

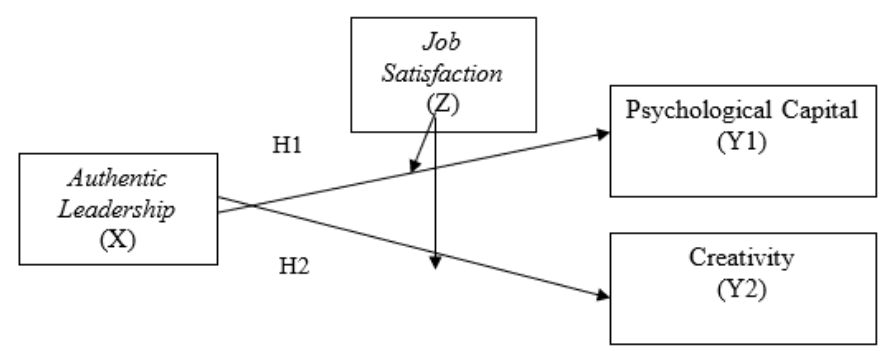

H1.There is an effect of authentic leadership on creativity

$\mathrm{H} 2$.There is an effect of authentic leadership on psychological capital.

H3. There is an effect of authentic leadership on creativity moderated by job satisfaction

H4.There is an effect of authentic leadership on psychological capital moderated by job satisfaction

\section{Research methods}

The research used in this research is quantitative research. According to Ostlund, Kidd, Wengström, \& Rowa-Dewar (2011). Quantitative research is a method known as a positivistic method because it is based on the philosophy of positivism. This method is a scientific method because it meets scientific principles, namely concrete / empirical, objective, measurable, rational, and systematic. This method is called a quantitative method because the research data is in the form of numbers and the analysis uses statistics. This study uses data analysis with the help of Smart PLS version 2.0 software that runs on computer media. PLS (Partial Least Square). PLS is 
a variant-based SEM statistical method designed to explain multiple regressions when a detailed problem occurs in the data. Hypothesis testing is a procedure based on sample evidence and is used to determine whether a hypothesis is a plausible statement and therefore not rejected, or the hypothesis is unreasonable and, therefore, should be rejected. This hypothesis is tested at the 0.05 significance level (confidence level $95 \%$ ). To find out the decision making of hypothesis testing is done by comparing the level of significance and alpha (0.05)

In this study, the data used are quantitative data by collecting (1) primary data, namely in the form of distributing questionnaires in the field to employees of Telecommunications Company (Telkom) and (2) secondary data in this study are literature, books, literature studies, and online media that can be found in libraries or the internet as supporting information for this research. The sample used in this study amounted to 100 . The independent variable in this study was authentic leadership (X1), the dependent variable was psychological capital (Y1) and creativity (Y2), while the moderating variable was job satisfaction $(\mathrm{Z})$.

\section{Research result}

\subsection{Evaluate Measurement (Outer) Model}

\subsubsection{Convergent Validity}

\begin{tabular}{|c|c|c|c|c|c|c|}
\hline & $\begin{array}{l}\text { Auth } \\
\text { entic } \\
\text { Lead } \\
\text { ershi } \\
\text { p }\end{array}$ & $\begin{array}{l}\mathrm{Cr} \\
\text { ea } \\
\text { tiv } \\
\text { ity }\end{array}$ & $\begin{array}{l}\text { Job } \\
\text { Sati } \\
\text { sfac } \\
\text { tion }\end{array}$ & $\begin{array}{l}\text { Moder } \\
\text { ating } \\
\text { Effect } \\
\text { Creativ } \\
\text { ity }\end{array}$ & $\begin{array}{l}\text { Moderatin } \\
\text { g Effect } \\
\text { Psycholog } \\
\text { ical } \\
\text { Capital }\end{array}$ & $\begin{array}{l}\text { Psyc } \\
\text { holog } \\
\text { ical } \\
\text { Capit } \\
\text { al }\end{array}$ \\
\hline AL1 & 0846 & & & & & \\
\hline AL2 & 0.752 & & & & & \\
\hline AL3 & 0.770 & & & & & \\
\hline AL4 & 0.787 & & & & & \\
\hline AL5 & 0.700 & & & & & \\
\hline AL6 & 0.853 & & & & & \\
\hline AL7 & 0.753 & & & & & \\
\hline AL8 & 0.753 & & & & & \\
\hline $\begin{array}{l}\text { Authentic } \\
\text { Leadershi } \\
\text { p * Job } \\
\text { Satisfactio } \\
\text { n }\end{array}$ & & & & & 1,836 & \\
\hline $\begin{array}{l}\text { Authentic } \\
\text { Leadershi } \\
\text { p * Job } \\
\text { Satisfactio } \\
\text { n }\end{array}$ & & & & 1,836 & & \\
\hline CR1 & & $\begin{array}{r}0 . \\
76 \\
7\end{array}$ & & & & \\
\hline CR2 & & $\begin{array}{c}0 . \\
76\end{array}$ & & & & \\
\hline
\end{tabular}

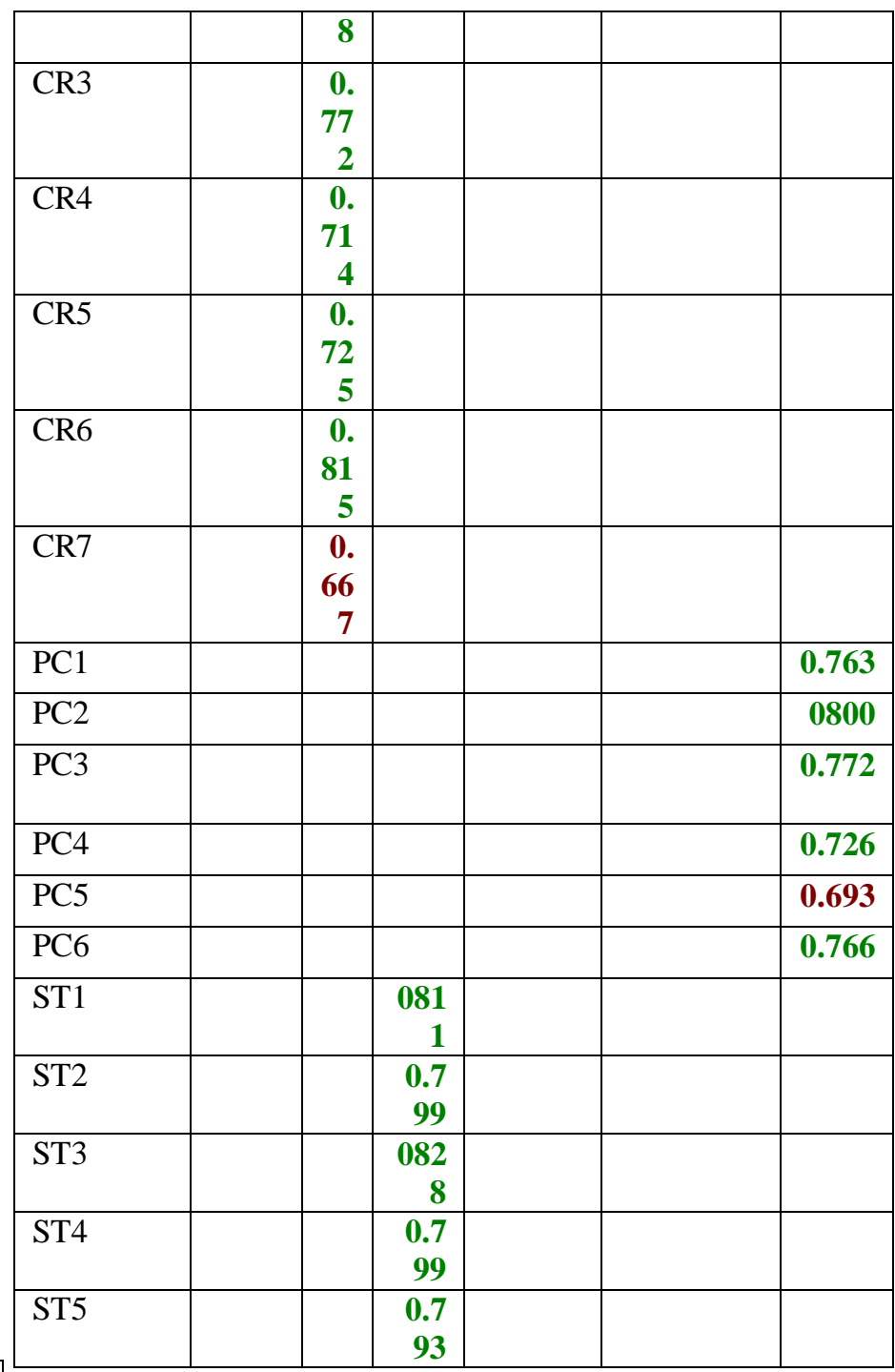

\subsubsection{Discriminate Validity \& Composite} Reliability

\begin{tabular}{|c|c|c|c|c|}
\hline & $\begin{array}{l}\text { Cronba } \\
\text { ch's } \\
\text { Alpha }\end{array}$ & $\begin{array}{l}\mathrm{rh} \\
\mathrm{O}_{-} \\
\mathrm{A}\end{array}$ & $\begin{array}{l}\text { Composi } \\
\text { te } \\
\text { Reliabilit } \\
\text { y }\end{array}$ & $\begin{array}{l}\text { Average } \\
\text { Variance } \\
\text { Extracted } \\
\text { (AVE) }\end{array}$ \\
\hline $\begin{array}{l}\text { Authentic } \\
\text { Leadership }\end{array}$ & 0.906 & $\begin{array}{r}0 . \\
90 \\
8\end{array}$ & 0.924 & 0.606 \\
\hline Creativity & 0868 & $\begin{array}{l}08 \\
70\end{array}$ & 0.899 & 0.560 \\
\hline Job Satisfaction & 0.865 & $\begin{array}{l}08 \\
67\end{array}$ & 0.903 & 0.649 \\
\hline $\begin{array}{l}\text { Moderating } \\
\text { Effect Creativity }\end{array}$ & 1,000 & $\begin{array}{r}1, \\
00 \\
0\end{array}$ & 1,000 & 1,000 \\
\hline $\begin{array}{l}\text { Moderating } \\
\text { Effect } \\
\text { Psychological } \\
\text { Capital }\end{array}$ & 1,000 & $\begin{array}{r}\mathbf{1 ,} \\
00 \\
0\end{array}$ & 1,000 & 1,000 \\
\hline $\begin{array}{l}\text { Psychological } \\
\text { Capital }\end{array}$ & 0849 & $\begin{array}{l}08 \\
56\end{array}$ & 0.888 & 0.569 \\
\hline
\end{tabular}

4.2 Evaluate the Structural Model or Inner Model 


\begin{tabular}{|c|c|c|c|}
\hline & (O) & & \\
\hline $\begin{array}{l}\text { Authentic } \\
\text { Leadership } \\
\text { towards } \\
\text { Creativity }\end{array}$ & 0.638 & 5,364 & 0.000 \\
\hline $\begin{array}{l}\text { Authentic } \\
\text { Leadership } \\
\text { to } \\
\text { Psychologic } \\
\text { al Capital }\end{array}$ & 0.717 & 7,275 & 0.000 \\
\hline $\begin{array}{l}\text { Job } \\
\text { Satisfaction } \\
\text { with } \\
\text { Creativity }\end{array}$ & 0.093 & 1,050 & 0.294 \\
\hline $\begin{array}{l}\text { Job } \\
\text { Satisfaction } \\
\text { with } \\
\text { Psychologic } \\
\text { al Capital }\end{array}$ & 0.107 & 1,260 & 0.208 \\
\hline $\begin{array}{l}\text { Authentic } \\
\text { Leadership } \\
\text { to Creativity } \\
\text { moderated } \\
\text { by Job } \\
\text { Satisfaction }\end{array}$ & 0.122 & 3,167 & 0.002 \\
\hline $\begin{array}{l}\text { Authentic } \\
\text { Leadership } \\
\text { to } \\
\text { Psychologic } \\
\text { al Capital is } \\
\text { moderated } \\
\text { by Job } \\
\text { Satisfaction }\end{array}$ & 0.078 & 2,522 & 0.012 \\
\hline
\end{tabular}

\section{Discussion}

\subsection{The influence of authentic leadership (X) variables on Creativity (Y2)}

Based on the results of statistical calculations the effect of the authentic leadership (X) variable on Creativity (Y2) shows that the p-value is smaller than the $\alpha$ value $(0.000 \leq 0.05)$. This value shows that the results are positive and significant. These results explain that the authentic leadership variable has an influence on Creativity. This result is also supported by statements from Cerne, Jaklic, \& Skerlavaj (2013).

Which states that authentic leadership is believed to be able to create employee creativity and innovation. In other studies, it is also stated that leadership positively and significantly affects employee creativity directly or indirectly through Authentic Leadership. (Zhang, X., \& Zhou, 2014).

\subsection{The effect of the authentic leadership variable (X) on psychological capital (Y1)}

Based on the results of statistical calculations the effect of the authentic leadership variable (X) on psychological capital (Y1) shows that the p-value is smaller than the $\alpha$ value $(0.000 \leq 0.05)$. Based on these calculations, positive and significant results are obtained. The results of this study indicate that authentic leadership has an influence on psychological capital. These results are also supported by statements from Wang, Sui, Luthans, Wang, \& Wu (2014) which state that companies that implement authentic and integrated leadership can increase a sense of comfort and positive energy for employees who work at the company.

\subsection{The influence of authentic leadership on creativity is moderated by job satisfaction}

Based on the statistical calculation of the effect of authentic leadership on creativity moderated by job satisfaction, it shows that the p-value is smaller than the $\alpha$ value $(0.002 \leq 0.05)$. The beta value is 0.122 . Based on these calculations, positive and significant results were obtained. The results of this study indicate that authentic leadership moderated by job satisfaction has an influence on creativity. These results are also supported by statements from Wang, Sui, Luthans, Wang, \& Wu (2014) which state that companies that apply authentic and integrated leadership can increase a sense of comfort and positive energy for employees who work at the company to create innovations. new.

\subsection{The effect of authentic leadership on psychological capital is moderated by job satisfaction}

Based on the statistical calculation of the effect of authentic leadership on psychological capital moderated by job satisfaction, it shows that the pvalue is smaller than the $\alpha$ value $(0.012 \leq 0.05)$. The value in beta is 0.078 so that a positive and significant result is obtained. These results indicate that authentic leadership moderated by job satisfaction has an influence on psychological capital. This is supported by the results of research by Megeirhi, Kilic, Avci, Afsar, \& Abubakar (2018) which state that authentic leadership has a positive effect on job satisfaction moderated by job satisfaction.

\section{Conclusion}

The results of this study indicate that the authentic leadership variable has a positive and significant effect on Creativity. Authentic leadership has a positive and significant effect on psychological capital. authentic leadership moderated job satisfaction has an influence on creativity. authentic leadership moderated by job satisfaction has an influence on psychological capital. 


\section{References}

[1] Tayibnapis, AZ, Wuryaningsih, LE, \& Gora, R. (2018). Indonesia's Efforts to Achieve Globally Competitive Human Resources. International Journal of Humanities and Social Science Invention (IJHSSI), 7 (8), 01-06.

[2] Lee, JY (2018). The effects of job characteristics on the team creativity of distribution companies: Moderating effects of transformational leadership. The Journal of Asian Finance, Economics, and Business, 5 (4), 161-172.

[3] Černe, M., Jaklič, M., \& Škerlavaj, M. (2013). Authentic leadership, creativity, and innovation: A multilevel perspective. Leadership, 9 (1), 6385.

[4] Allen, DG, \& Shanock, LR (2013). Perceived organizational support and embeddedness as key mechanisms connecting socialization tactics to commitment and turnover among new employees. Journal of Organizational Behavior, 34 (3), 350-369.

[5] Slåtten, T., \& Mehmetoglu, M. (2015). The effects of transformational leadership and perceived creativity on innovation behavior in the hospitality industry. Journal of Human Resources in Hospitality \& Tourism, 14 (2), 195-219.

[6] Malik, N., \& Dhar, RL (2017). Authentic leadership and its impact on extra role behavior of nurses. Personnel Review.

[7] Zhang, X., \& Zhou, J. (2014). Empowering leadership, uncertainty avoidance, trust, and employee creativity: Interaction effects and a mediating mechanism. Organizational Behavior and Human Decision Processes, 124 (2), 150164.

[8] Wang, HUI, Sui, Y., Luthans, F., Wang, D., \& $\mathrm{Wu}, \mathrm{Y}$. (2014). Impact of authentic leadership on performance: Role of followers' positive psychological capital and relational processes. Journal of Organizational Behavior, 35 (1), 521.

[9] Tongchaiprasit, P., \& Ariyabuddhiphongs, V. (2016). Creativity and turnover intention among hotel chefs: The mediating effects of job satisfaction and job stress. International Journal of Hospitality Management, 55, 33-40.

[10] Badran, MA, \& Youssef-Morgan, CM (2015). Psychological capital and job satisfaction in Egypt. Journal of Managerial Psychology.

[11] Olaniyan, OS, \& Hystad, SW (2016). Employees' psychological capital, job satisfaction, insecurity, and intentions to quit: The direct and indirect effects of authentic leadership. Revista de Psicología del Trabajo y de las Organizaciones, 32 (3), 163-171.

[12] Hsieh, YH, \& Chen, HM (2011). Strategic fit among business competitive strategy, human resource strategy, and reward system. Academy of Strategic Management Journal, 10 (2), 11.

[13] Schreyögg, G., \& Sydow, J. (2010). Crossroads - organizing for fluidity? Dilemmas of new organizational forms. Organization science, 21 (6), 1251-1262.

[14] Avey, JB, Reichard, RJ, Luthans, F., \& Mhatre, KH (2011). Meta - analysis of the impact of positive psychological capital on employee attitudes, behaviors, and performance. Human resource development quarterly, 22 (2), 127-152.

[15] Luthans, F., \& Youssef-Morgan, CM (2017). Psychological capital: An evidence-based positive approach. Annual review of organizational psychology and organizational behavior, 4, 339-366.

[16] Chen, MH, Chang, YY, \& Chang, YC (2015). Exploring individual-work context fit in affecting employee creativity in technologybased companies. Technological Forecasting and Social Change, 98, 1-12.

[17] Liu, D., Chen, XP, \& Yao, X. (2011). From autonomy to creativity: a multilevel investigation of the mediating role of harmonious passion. Journal of Applied Psychology, 96 (2), 294.

[18] Kremer, H., Villamor, I., \& Aguinis, H. (2019). Innovation leadership: Best-practice recommendations for promoting employee creativity, voice, and knowledge sharing. Business Horizons, 62 (1), 65-74.

[19] Insoll, L., \& Mäkikyrö, J. (2018). Creativity in Business Incubators: A Qualitative Study of the Influencers of Startup Employee Creativity in Incubators.

[20] Gong, Y., Cheung, SY, Wang, M., \& Huang, JC (2012). Unfolding the proactive process for creativity: Integration of the employee proactivity, information exchange, and psychological safety perspectives. Journal of management, 38 (5), 1611-1633.

[21] Avey, JB, Luthans, F., \& Youssef, CM (2010). The additive value of positive psychological capital in predicting work attitudes and behaviors. Journal of management, 36 (2), 430-452.

[22] Sweetman, D., \& Luthans, F. (2010). The power of positive psychology: Psychological capital and work engagement. Work 
engagement: A handbook of essential theory and research, 54, 68.

[23] Verleysen, B., Lambrechts, F., \& Van Acker, F. (2015). Building psychological capital with appreciative inquiry: Investigating the mediating role of basic psychological need satisfaction. The Journal of Applied Behavioral Science, 51 (1), 10-35.

[24] Avey, JB, Luthans, F., Smith, RM, \& Palmer, NF (2010). Impact of positive psychological capital on employee well-being over time. Journal of occupational health psychology, 15 (1), 17.

[25] Toor, SUR, \& Ofori, G. (2010). Positive psychological capital as a source of sustainable competitive advantage for organizations. Journal of Construction Engineering and Management, 136 (3), 341-352.

[26] Dul, J., Bruder, R., Buckle, P., Carayon, P., Falzon, P., Marras, WS, ... \& van der Doelen, B. (2012). A strategy for human factors / ergonomics: developing the discipline and profession. Ergonomics, 55 (4), 377-395.

[27] Rego, A., Sousa, F., Marques, C., \& e Cunha, MP (2012). Authentic leadership promoting employees' psychological capital and creativity. Journal of business research, 65 (3), 429-437.

[28] Amunkete, S., \& Rothmann, S. (2015). Authentic leadership, psychological capital, job satisfaction and intention to leave in stateowned enterprises. Journal of Psychology in Africa, 25 (4), 271-281.

[29] Wu, JB, Tsui, AS, \& Kinicki, AJ (2010). Consequences of differentiated leadership in groups. Academy of Management Journal, 53 (1), 90-106.

[30] Sauer, SJ (2011). Taking the reins: The effects of new leader status and leadership style on team performance. Journal of Applied Psychology, 96 (3), 574.

[31] García-Morales, VJ, Jiménez-Barrionuevo, MM, \& Gutiérrez-Gutiérrez, L. (2012). Transformational leadership influence on organizational performance through organizational learning and innovation. Journal of business research, 65 (7), 1040-1050.

[32] Khan, SN (2010). Impact of authentic leaders on organization performance. International Journal of Business and Management, 5 (12), 167.

[33] Pieterse, AN, Van Knippenberg, D., Schippers, M., \& Stam, D. (2010). Transformational and transactional leadership and innovative behavior: The moderating role of psychological empowerment. Journal of organizational behavior, 31 (4), 609-623.

[34] Loon, M., Lim, YM, Lee, TH, \& Tam, CL (2012). Transformational leadership and jobrelated learning. Management Research Review.

[35] Liu, SM, Liao, JQ, \& Wei, H. (2015). Authentic leadership and whistleblowing: Mediating roles of psychological safety and personal identification. Journal of Business Ethics, 131 (1), 107-119.

[36] Olaniyan, OS (2017). Authentic Leadership, Psychological Capital, and Employees' WellBeing. In The positive side of occupational health psychology (pp. 45-64). Springer, Cham.

[37] Jung, HS, \& Yoon, HH (2015). The impact of employees' positive psychological capital on job satisfaction and organizational citizenship behaviors in the hotel. International Journal of Contemporary Hospitality Management.

[38] Dugguh, SI, \& Dennis, A. (2014). Job satisfaction theories: Traceability to employee performance in organizations. IOSR journal of business and management, 16 (5), 11-18.

[39] Parvin, MM, \& Kabir, MN (2011). Factors affecting employee job satisfaction of the pharmaceutical sector. Australian journal of business and management research, 1 (9), 113.

[40] Luthans, F., \& Youssef-Morgan, CM (2017). Psychological capital: An evidence-based positive approach. Annual review of organizational psychology and organizational behavior, 4, 339-366.

[41] Fazylova, S., \& Rusol, I. (2016). Development of Creativity in Schoolchildren through Art. Czech-Polish Historical \& Pedagogical Journal, 8 (2).

[42] Joo, BK, McLean, GN, \& Yang, B. (2013). Creativity and human resource development: An integrative literature review and a conceptual framework for future research. Human Resource Development Review, 12 (4), 390-421.

[43] Chini, B. (2011). Developing Organizational Creativity: Researching contextual factors that enhance or restrict the output of creative potential (Master's thesis, Open Universiteit Nederland).

[44] De Stobbeleir, KE, Ashford, SJ, \& Buyens, D. (2011). Self-regulation of creativity at work: The role of feedback-seeking behavior in creative performance. Academy of management journal, 54 (4), 811-831.

[45] Avolio, BJ, Wernsing, T., \& Gardner, WL (2018). Revisiting the development and 
validation of the authentic leadership questionnaire: Analytical clarifications. Journal of Management, 44 (2), 399-411.

[46] Rego, A., Sousa, F., Marques, C., \& e Cunha, MP (2012). Authentic leadership promoting employees' psychological capital and creativity. Journal of business research, 65 (3), 429-437.

[47] Putri, A., Kartini, K., \& Yuanita, P. (2020, October). The Effectiveness of Learning Tools Based on Discovery Learning That Integrates 21st Century Skills to Mathematical Critical Thinking Ability in Trigonometric Materials in High School. In Journal of Physics: Conference Series (Vol. 1655, No.1, p. 012071). IOP Publishing.

[48] Hannah, ST, Avolio, BJ, \& Walumbwa, FO (2011). Relationships between authentic leadership, moral courage, and ethical and prosocial behaviors. Business Ethics Quarterly, 21 (4), 555-578.

[49] Gigol, T. (2020). Influence of authentic leadership on unethical pro-organizational behavior: The intermediate role of work engagement. Sustainability, 12 (3), 1182.

[50] Bamford, M., Wong, CA, \& Laschinger, H. (2013). The influence of authentic leadership and areas of worklife on work engagement of registered nurses. Journal of nursing management, 21 (3), 529-540.

[51] Weiss, M., Razinskas, S., Backmann, J., \& Hoegl, M. (2018). Authentic leadership and leaders' mental well-being: An experience sampling study. The Leadership Quarterly, 29 (2), 309-321.

[52] Sharma, A., Agrawal, R., \& Khandelwal, U. (2019). Developing ethical leadership for business organizations. Leadership \& Organization Development Journal.

[53] Maharani, V., Troena, EA, \& Noermijati, N. (2013). Organizational citizenship behavior role in mediating the effect of transformational leadership, job satisfaction on employee performance: Studies in PT bank Syariah Mandiri Malang, East Java. International Journal of Business and Management, 8 (17), 112.

[54] Amunkete, S., \& Rothmann, S. (2015). Authentic leadership, psychological capital, job satisfaction and intention to leave in stateowned enterprises. Journal of Psychology in Africa, 25 (4), 271-281.
[55] Petan, L., \& Bocarnea, M. (2016). Follower perceptions of authentic leadership: A comparison between respondents from Romania and the United States. Procedia-Social and Behavioral Sciences, 221, 142-150.

[56] Choi, YG, Kwon, J., \& Kim, W. (2013). Effects of attitudes vs experience of workplace fun on employee behaviors. International Journal of Contemporary Hospitality Management.

[57] Lane, KA, Esser, J., Holte, B., \& McCusker, MA (2010). A study of nurse faculty job satisfaction in community colleges in Florida. Teaching and Learning in Nursing, 5 (1), 16-26.

[58] Tan, TH, \& Waheed, A. (2011). Herzberg's motivation-hygiene theory and job satisfaction in the Malaysian retail sector: The mediating effect of love of money.

[59] Jehanzeb, K., \& Mohanty, J. (2018). Impact of employee development on job satisfaction and organizational commitment: person organization fit as moderator. International Journal of Training and

[60] Development, 22 (3), 171-191. Frooman, J., Mendelson, MB, \& Murphy, JK (2012). Transformational and passive avoidant leadership as determinants of absenteeism. Leadership \& Organization Development Journal.

[61] Yücel, İ. (2012). Examining the relationships among job satisfaction, organizational commitment, and turnover intention: An empirical study.

[62] Östlund, U., Kidd, L., Wengström, Y., \& Rowa-Dewar (2011). Combining qualitative and quantitative research within mixed method research designs: a methodological review. International journal of nursing studies, 48 (3), 369-383.

[63] Atmojo, M. (2015). The influence of transformational leadership on job satisfaction, organizational commitment, and employee performance. International research journal of business studies, 5 (2).

\section{Author Profile}

M Monday HAR received the Dr. and MS degrees in Management from STIE APRIN Palembang.

Ali Sadikinreceived the Dr. and MS degrees in Management from STIE APRIN Palembang. 